\title{
Effect of Maternal Autoantibodies on Fetal Cardiac Conduction: An Experimental Murine Model
}

\author{
HIROSHI SUZUKI, EARL D. SILVERMAN, XUEJUN WU, CLAUDIA BORGES, SHUFANG ZHAO, \\ BONNIE ISACOVICS, AND ROBERT M. HAMILTON
}

Division of Cardiovascular Research [H.S., E.D.S., X.W., S.Z., B.I., R.M.H.], The Hospital for Sick

Children Research Institute, Toronto, Ontario, Canada, M5G 1X8, Division of Cardiology [H.S., R.M.H.],

Division of Rheumatology [E.D.S., C.B., B.I.], Department of Pediatrics, The Hospital for Sick Children,

Toronto, Ontario, Canada, M5G $1 X 8$

\begin{abstract}
ABS
The pathogenesis of congenital heart block (CHB) remains
unclear. The occurrence rate of neonatal CHB is low, even in
murine models of lupus erythematosus. The assessment of heart
block in murine maternal lupus models by measuring atrioven-
tricular conduction in neonatal offspring is potentially con-
founded by fetal wastage. We therefore sought to develop a
murine CHB model with a superior immune response and to use
embryonic Doppler echocardiography to observe conduction sys-
tem damage in the fetus. Mature 8 -wk-old female C3H/HeJ mice
( $n=43$ ) were immunized with $60 \mathrm{kD}$ Ro, $48 \mathrm{kD}$ La, or
recombinant calreticulin autoantigens. ELISA confirmed that
significant serum autoantibodies developed in all three immu-
nized groups when compared with controls. Starting at $13 \mathrm{~d}$ of
gestation, a significantly lower fetal heart rate (HR) and a higher
percentage of fetal bradycardia/atrioventricular block (AVB,
nonadvanced second degree) were observed in all immunized
\end{abstract}
A century has passed since the first description of $\mathrm{CHB}$ in the medical literature (1). The disease is defined as the demonstration of the establishment of heart block "in a young patient by graphic records" and "there must be evidence of the existence of the slow pulse at an early age and absence of a history of any infection which might cause the condition after birth" (2). The ECG criteria specify that atrial and ventricular activity are completely dissociated, the ventricular rate is slower, and no captured beats are present. This definition remains as the standard for the diagnosis of $\mathrm{CHB}$.

The pathogenesis of CHB remains unclear. The association of the disease with maternal autoantibodies has been recog-

Received December 11, 2003; accepted August 6, 2004.

Correspondence: Robert M. Hamilton, M.D., Room 1503D, The Hospital for Sick Children, 555 University Ave., Toronto, Ontario M5G 1X8, Canada; e-mail: robert.hamilton@sickkids.ca

Supported by a grant from the Medical Research Council of Canada to R.M.H. and E.D.S. (MRC operating grant \#MT15052; now the Canadian Institutes of Health Research).

DOI: 10.1203/01.PDR.0000155947.82365.E4 groups, compared with controls. There was 9-18\% nonadvanced second-degree AVB in immunized groups and $0 \%$ in controls at $<18 \mathrm{~d}$ of gestation. Neonatal electrocardiograms demonstrated only $1^{\circ}$ AVB in immunized groups. Maternal immunization with $60 \mathrm{kD}$ Ro, $48 \mathrm{kD}$ La, or recombinant calreticulin autoantigens resulted in AVB in a significant percentage of fetuses, however, lesser degrees of AVB were seen at birth. Significant fetal bradycardia and AVB may be missed by assessment only at birth in murine models of CHB due to fetal wastage. (Pediatr Res 57: 557-562, 2005)
AVB, atrioventricular block
CHB, congenital heart block
HR, heart rate

Abbreviations nized since $1977(3,4)$. Immune-mediated damage to the fetal conduction system by maternal autoantibodies crossing the placenta in early to mid-gestation has been proposed $(5,6)$ but not confirmed as the mechanism of injury in CHB. Serological studies have demonstrated an association with anti-Ro and anti-La antibodies that is sensitive but not specific for the development of CHB (5,7-10). It has also been suggested that there is an association between anti-calreticulin antibodies and CHB (11).

Research into the pathogenesis of CHB has been hindered by its low incidence in infants ( 1 in 14,000 births) (12) and by the absence of a naturally occurring animal model. Therefore, experimental models have been developed, including neonatal rabbit cardiac tissue (13), adult rabbit Langendorff preparations (14), and murine models $(15,16)$. The most promising model has examined the exposure to autoantibodies during pregnancy (15-17). Neonatal assessment of offspring demonstrated the rare occurrence of second- or third-degree AVB. Fetal assessment was not performed in these reports and fetal wastage was not assessed. 
Fetal rhythm in the human is normally assessed by fetal echocardiography, where electrical events in the heart are inferred by their resulting mechanical events. These mechanical events may consist of chamber wall or valve motion detected by M-mode echocardiography (18) or tissue velocity imaging (19), or the resultant intracardiac blood flow detected by Doppler echocardiography (20). Huhta and colleagues $(21,22)$ have demonstrated a technique of embryonic Doppler echocardiography in the mouse and suggested that it may be a useful technique in assessing heart rhythm in mouse models of disease. Using this technique to assess fetal rhythm, we examined the effect of maternal immunization with Ro, La, and calreticulin autoantigens, the subsequent development of maternal autoantibodies, and the development of the fetal cardiac conduction system disease.

\section{METHODS}

Animal protocol. The animal care committee of the Hospital for Sick Children Research Institute approved the experimental design of this study.

Immunization. Mature 8-wk-old female $\mathrm{C} 3 \mathrm{H} / \mathrm{HeJ}$ mice (Charles River Laboratories, Wilmington, MA) were immunized by subcutaneous injection into the back of the neck with $70 \mu \mathrm{g}$ of bovine affinity-purified $60 \mathrm{kD} \mathrm{Ro}$, affinity-purified $48 \mathrm{kD}$ La (both generous gifts of Immunovision Inc., Springvale, AR), or recombinant calreticulin (generous gift of Dr. R. Sontheimer, University of Iowa, Iowa City, IA) with $0.3 \mathrm{~mL}$ Freund's complete adjuvant (Invitrogen, Carlsbad CA). Bovine Ro antigen was used because recombinant Ro antigen was not available from commercial or collaborative sources. We chose to immunize with the $60 \mathrm{kD}$ Ro because short peptides from this antigen had successfully produced autoimmunity in a rabbit model (23) and anti-60 kD Ro antibodies had been shown to be associated with isolated CHB $(24,25)$. The mice were boosted twice at $10-d$ intervals by subcutaneous injection with 50 $\mu \mathrm{g}$ of the same antigen with $0.5 \mathrm{~mL}$ Freund's incomplete adjuvant (Invitrogen). In controls, antigen was replaced by $0.01 \mathrm{M}, \mathrm{pH} 7.6$, sterilized Tris PBS buffer. Blood samples were collected through orbital sinus bleed at $7 \mathrm{~d}$ after the second boost and on the day of delivery. Sera were assessed for the presence of anti-Ro, anti-La, and anti-calreticulin antibodies by our previously described ELISA (26) using a MicroELISA Reader (Dynatech, Alexandria, VA). A result was considered positive if it was $>2$ SD above the value obtained for controls.

Fetal and neonatal assessment. The immunized mice were mated overnight and successful impregnation was confirmed by the presence of a vaginal plug ( $0 \mathrm{~d}$ of gestation). Starting at $13 \mathrm{~d}$ of gestation, fetal echocardiographic assessment was performed on each mother. The mother was sedated by intraperitoneal injection with chloral hydrate $(0.36 \mathrm{mg} / \mathrm{g})$ and gently restrained Fetal echocardiograms were performed with a $10 \mathrm{MHz}$ in-line probe and Mark 9 ultrasound machine (ATL Ultrasound, Philips Medical Systems, Markham, Ontario, Canada) and recorded on SVHS videotape. Online measurements of fetal HR were performed with the software package provided. Fetal echocardiography assessment was similar to that Huhta and colleagues (21) described previously. We systematically scanned from the midline along each horn of the bicornuate uterus, identifying the individual fetus as right or left medial, inferior, mid, or superior in terms of its position in the uterus to avoid repeated measurements from the same one. Second-degree AVB has been occasionally found in studies of normal human fetuses during echocardiographic examination, where it was thought to be related to transient increases in uterine pressure due to excessive probe pressure. We intentionally avoided excessive probe pressure and we used a flaccid gel-filled glove finger as a standoff over the maternal mouse abdomen to prevent the transmission of probe pressure.

Surface electrocardiograms (ECG) were performed within the first $24 \mathrm{~h}$ at room temperature in the neonatal mice. Anesthesia was not necessary. This was achieved using a four-limb electrocardiographic lead system attached with weakened clips and amplification with E for M ECG amplifiers (now GE Medical Systems, Inc., Fairfield, CT), and was recorded using an analog-todigital system at $1000 \mathrm{HZ}$ (Labview 2.1, National Instruments, Austin, TX) for subsequent analysis.

We compared the results of the ECG performed before $18 \mathrm{~d}$ of gestation with those after $18 \mathrm{~d}$ of gestation. We also compared the number of live-born pups born to the immunized mothers to controls. Within $24 \mathrm{~h}$ of birth, the number of live pups was counted to calculate parity, defined as live births per pregnancy.
Statistical analysis. Statistical analysis was performed using Statistica software (Release 4, StatSoft, Tulsa, OK). Data were presented as mean \pm SD. Differences among groups were evaluated by one-way ANOVA with Scheffe's procedure or Fisher's exact test as appropriate. A $p$ value $<0.05$ was considered statistically significant.

\section{RESULTS}

Production of autoantibodies. Immunization of all female mice with the proteins of $60 \mathrm{kD} \mathrm{Ro}, 48 \mathrm{kD} \mathrm{La}$, or recombinant calreticulin resulted in antibodies directed against the immunizing protein (Table 1). Immunization with $60 \mathrm{kD}$ Ro resulted in the production of not only anti-Ro antibodies but also anti-La and anti-calreticulin antibodies. However, immunization with $48 \mathrm{kD}$ La resulted in the production of only anti-Ro antibodies but not anti-calreticulin antibodies (in addition to the production of anti-La antibodies), whereas immunization with recombinant calreticulin did not result in the production of anti-Ro or anti-La antibodies.

Embryonic cardiac Doppler. After mating of immunized female mice, serial echocardiograms were performed on the developing fetuses. Figure 1 demonstrates a normal aortic out flow pattern of fetal Doppler echocardiography. Figure 2 demonstrates a fetal Doppler pattern from an "inflow-outflow" view in a fetus with sinus bradycardia. Sinus bradycardia is confirmed by the 1:1 relationship between the mitral inflow (e and a waves) and subaortic outflow Doppler velocity profiles (Ao), although these ideal views were recorded only in approximately one third of cases. Therefore, nonadvanced seconddegree AVB, including Wenckbach-type and Mobitz type II, was detected by the presence of both Wenckebach-type periodicity with dropped outflows and the sudden halving of the outflows during the embryonic Doppler examinations. Typical patterns of nonadvanced second-degree AVB are shown in Figure 3. We did not detect advanced second- or third-degree AVB in any group. Theoretically, embryonic Doppler echocardiography can be used for detecting advanced second- and third-degree AVB if a true inflow-outflow view is recorded and the Doppler flow profiles demonstrate that inflow and outflow are dissociated. However, we could not consistently identify the inflow-outflow view and profile in our experiments. Hence advanced second- or third-degree AVB might be detected as just bradycardia. We cannot exclude the possibility blocked atrial premature beats are recognized as nonadvanced seconddegree AVB because "a" wave could not be detected clearly. We speculate, however, the possibility was rare because this Doppler pattern was not seen in any of the control pregnancies.

Table 1. Maternal serum antibody titers (in optical density) after the third immunization with each individual protein

\begin{tabular}{lcll}
\hline \multirow{2}{*}{\multicolumn{1}{c}{ Immunogen }} & \multicolumn{3}{c}{ Antibodies } \\
\cline { 2 - 4 } Control $(n=18)$ & $0 / 18(0 \%)$ & $0 / 18(0 \%)$ & $0 / 18(0 \%)$ \\
$60 \mathrm{kD} \mathrm{Ro}(n=12)$ & $12 / 12(100 \%)$ & $9 / 12(100 \%)$ & $6 / 12(50 \%)$ \\
$48 \mathrm{kD} \mathrm{La}(n=7)$ & $5 / 7(71.4 \%)$ & $7 / 7(100 \%)$ & $0 / 7(100 \%)$ \\
Calreticulin $(n=6)$ & $0 / 6(0 \%)$ & $0 / 6(0 \%)$ & $6 / 6(100 \%)$ \\
\hline
\end{tabular}

Values are the number of positives/the total number; percentage positive is shown in brackets. Positive was defined as $>2 \mathrm{SD}$ above the value obtained for controls. 


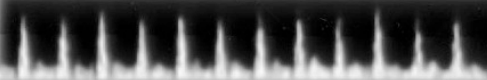 "in'in'min'm}

Figure 1. Embryonic mouse Doppler pattern of aortic outflow confirms a normal heart rate of 353 beats per minute.

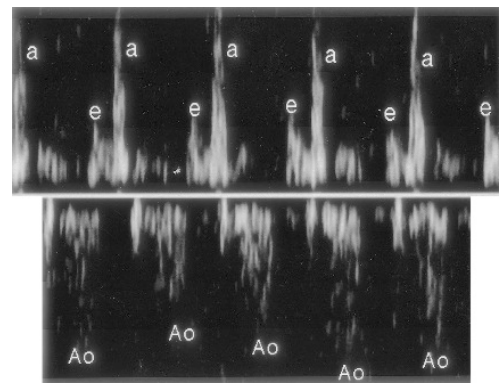

Figure 2. Embryonic mouse Doppler interrogation of flow in an "inflow/ outflow" region of the fetal mouse ventricle demonstrates sinus bradycardia. This can be differentiated from atrioventricular block by the identification of a 1:1 relationship between the inflow " $a$ " and " $v$ " waves and the aortic outflow tract tracing $(A o)$.

\section{A}

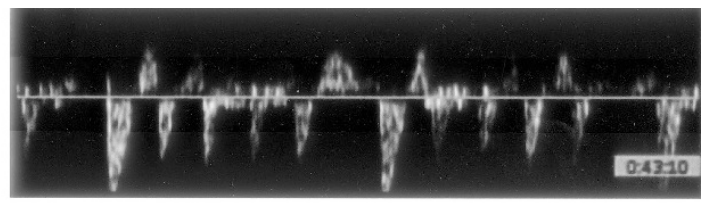

B

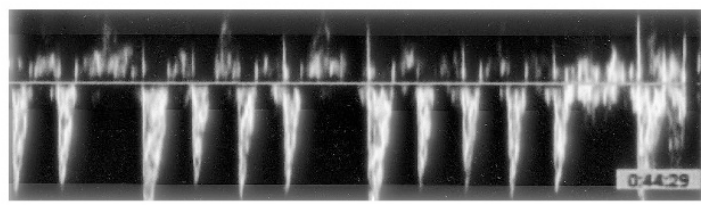

C

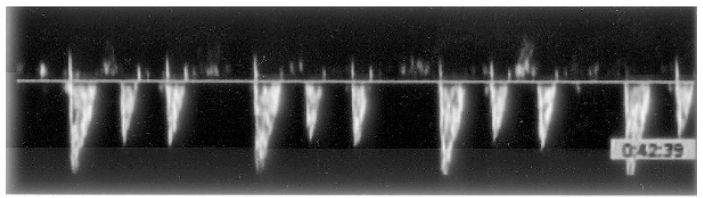

D

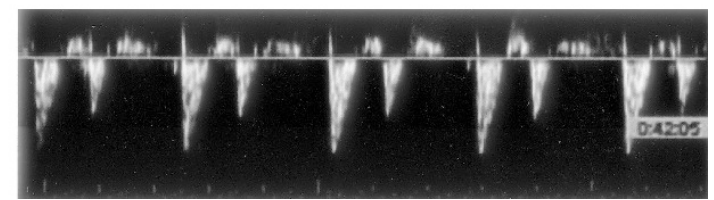

Figure 3. Embryonic mouse Doppler patterns of aortic outflow demonstrate varying Wenckebach periodicity in fetuses in the Ro-immunized group. Panel $A$ demonstrates the Doppler sample volume placed across the heart of a fetus and the resultant aortic outflow tracing with a $6: 5$ block. This progresses to a 5:4 block in panel $B$. Panel $C$ from a different fetus demonstrates a 4:3 block, which progresses to a $3: 2$ block in panel $D$.

Doppler findings were summarized as occurring at $<18 \mathrm{~d}$ of gestation or $>18 \mathrm{~d}$ of gestation (Table 2). Fetal bradycardia was defined as a HR below the lowest recorded value for controls, which was 140 beat per minute at $<18 \mathrm{~d}$ of gestation or 158 beat per minute at $>18 \mathrm{~d}$ of gestation. Bradycardia groups did not include nonadvanced second-degree AVB. Fig- ure 4 demonstrates second-degree AVB accompanied with sinus bradycardia.

Fetal HR and rhythm ( $<18$ d of gestation). The fetal HR in all immunized groups was significantly lower than that in controls $(p<0.01)$. The fetal HR of Ro-immunized group was significantly higher than that of the other immunized groups $(p<0.05)$. There was no significant difference in fetal HR between La- and calreticulin-immunized groups.

We examined the percentage of fetuses who had conduction abnormalities in all groups. Bradycardia was seen in $39 \%$ in the La-immunized group, $33 \%$ in the calreticulin-immunized group, and $21 \%$ in the Ro-immunized group. In total, bradycardia was seen in $28(29 \%)$ of 96 fetuses in the immunized groups compared with none in controls $(p \leq 0.0001$ by Fisher's exact test). Nonadvanced second-degree AVB was seen in $18 \%$ in La-immunized group, $12 \%$ in calreticulin-immunized group, and 9\% in Ro-immunized group. In total, nonadvanced second-degree AVB was seen in $12(13 \%)$ of 96 fetuses in the immunized groups as compared with none of controls had any signs of AVB ( $p \leq 0.0001$ by Fisher's exact test).

Fetal HR and rhythm ( $\geq 18$ d of gestation). At $\geq 18 \mathrm{~d}$ of gestation, fetal HR in all immunized groups was significantly lower than that in controls $(p<0.001)$. Again, there was a significantly increased incidence of bradycardia in Roimmunized (24\%), La-immunized $(20 \%)$, and calreticulinimmunized $(8 \%)$ groups. In total, bradycardia was seen in 15 $(20 \%)$ of 76 fetuses in the immunized groups compared with the absence of bradycardia seen in controls ( $p \leq 0.0001$ by Fisher's exact test). However, fetal HR was not significantly different between immunized groups. Similarly, nonadvanced second-degree AVB was seen in 3\% in the Ro-immunized group, $17 \%$ in the La-immunized group, and $8 \%$ in the calreticulin-immunized group. In total, nonadvanced second-degree AVB was seen in $15(16 \%)$ of 96 fetuses in the immunized groups compared with controls, none of which had any signs of AVB ( $p \leq 0.0001$ by Fisher's exact test).

Neonatal ECG. We could record surface ECG in 45 pups in controls and 77 pups in immunized groups. Figure 5 demonstrates neonatal recordings in each group. Neonatal HR in the Ro-immunized group was significantly lower than that in controls $(p<0.05)$ (Table 3). Second- or third-degree AVB was never observed in controls or immunized groups. Firstdegree AVB was defined as a PR interval $>2$ SD above the value obtained for controls. In total, first-degree AVB was seen in $10(13 \%)$ of 77 pups in the immunized groups as compared with one ( $2 \%$ ) of 45 controls ( $p<0.05$ by Fisher's exact test).

Parity. There were a total of 17 pregnancies in the control mice, with a mean of $5.5 \pm 2.0$ live-pups/pregnancy. This number is similar to the mean number of live births in the pregnancies of the Ro-immunized mothers $(4.8 \pm 1.9)$ and La-immunized mothers $(4.9 \pm 2.2)$ but was significantly more than that of the calreticulin-immunized mothers $(3.0 \pm 2.0$, $p<0.05)($ Table 4).

\section{DISCUSSION}

Complete CHB is an irreversible disease of the fetus and newborn associated with maternal autoantibodies. The mech- 
Table 2. Summary of embryonic cardiac Doppler interrogation in immunized and control groups

\begin{tabular}{|c|c|c|c|c|}
\hline Gestational age & Group & Bradycardia§ & Nonadvanced $2^{\circ}$ AVB & Heart rate $\S(\mathrm{bpm})$ \\
\hline \multirow[t]{3}{*}{$<\mathrm{d} 18$} & Control & $0 / 45(0 \%) \mathrm{I}$ & 0/45 (0.0\%)氏 & $289.0 \pm 151.1$ \\
\hline & 60 kD Ro & $9 / 44(20.5 \%)$ & $4 / 44(9.1 \%)$ & $199.9 \pm 98.5^{*}$ \\
\hline & 48 kD La & $11 / 28(39.3 \%)$ & $5 / 28(17.9 \%)$ & $154.6 \pm 58.1 * * * \dagger$ \\
\hline \multirow[t]{3}{*}{$\geq \mathrm{d} 18$} & Control & $0 / 52(0.0 \%) \mathrm{I}$ & $0 / 52(0.0 \%) \mathbb{\pi}$ & $312.1 \pm 85.3$ \\
\hline & 60 kD Ro & $8 / 33(24.2 \%)$ & $1 / 33(3.0 \%)$ & $213.2 \pm 95.9 * * *$ \\
\hline & $48 \mathrm{kD} \mathrm{La}$ & $6 / 30(20.0 \%)$ & $5 / 30(16.7 \%)$ & $247.6 \pm 107.2^{* *}$ \\
\hline
\end{tabular}

bpm, beat per minute.

$\S$ Values are the number of positives/the total number; percentage positive is shown in brackets.

$\S \S$ Values are mean $\pm \mathrm{SD}$.

If $p<0.0001$ compared with the total of the immunized groups by using Fisher's exact test.

$* p<0.01, * * p<0.001, * * * p<0.0001$ compared with control.

$\dagger p<0.05$; $\dagger p<0.01$ compared with $60 \mathrm{kD}$ Ro, using one-way ANOVA.

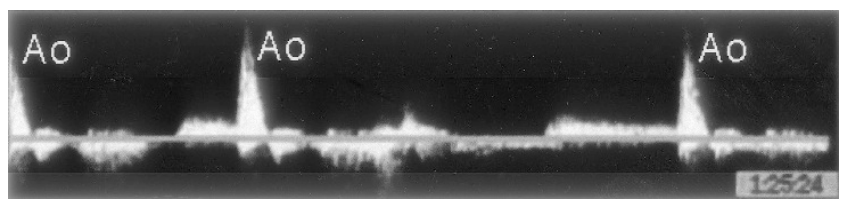

Figure 4. Embryonic mouse Doppler pattern of aortic outflow in the presence of both sinus bradycardia and atrioventricular block.

\section{Control}
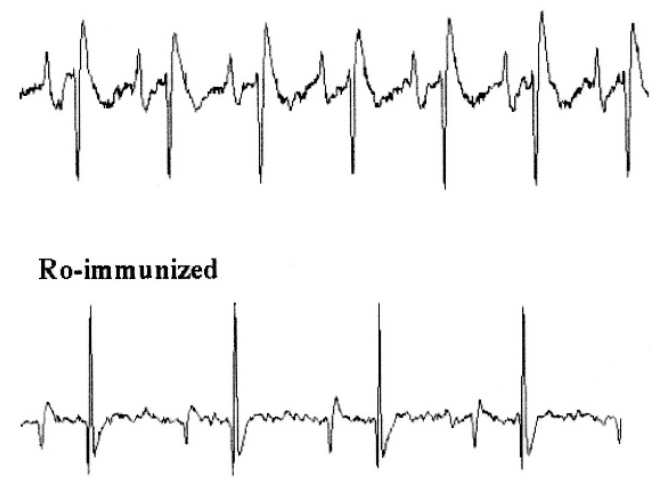

Calreticulin-immunized

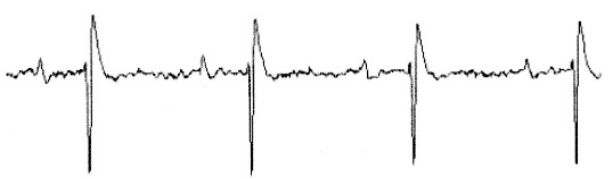

La-immunized

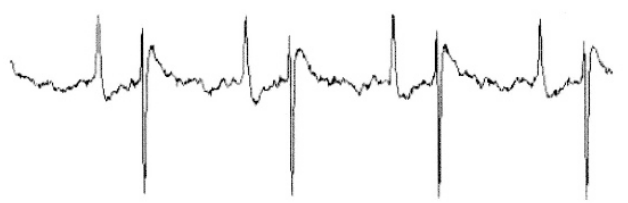

Figure 5. The standard limb lead ECG in a surviving mouse $<24$-h old in each group.

anism(s) leading to the conduction system disease in children of mothers with circulating anti-Ro and anti-La antibodies remains unclear. Although autoantibodies in the mothers of
Table 3. Neonatal ECG in immunized and control groups

\begin{tabular}{lll}
\hline \multicolumn{1}{c}{ Immunogen } & \multicolumn{1}{c}{$\begin{array}{c}\text { Heart rate } \\
(\mathrm{bpm})\end{array}$} & \multicolumn{1}{c}{$\mathrm{I}^{\circ} \mathrm{AVB} \S \S$} \\
\hline Control $(n=45)$ & $324.0 \pm 89.6$ & $1 / 45(2.2 \%) \dagger$ \\
$60 \mathrm{kD} \mathrm{Ro}(n=43)$ & $263.9 \pm 91.9^{*}$ & $6 / 43(14.0 \%)$ \\
$48 \mathrm{kD} \mathrm{La}(n=28)$ & $329.8 \pm 60.4$ & $2 / 28(7.2 \%)$ \\
Calreticulin $(n=6)$ & $287.7 \pm 85.5$ & $2 / 6(33.3 \%)$ \\
\hline
\end{tabular}

bpm, beat per minute. Values are mean $\pm \mathrm{SD}$.

$* p<0.05$ compared with control, using one-way ANOVA.

$\S \S$ Values are the number of positives/the total number; percentage positive is shown in brackets.

$\dagger p<0.05$ compared with the total of the immunized groups by using Fisher's exact test.

Table 4. Average number of pups per pregnancy (fetal parity) in immunized and control groups

\begin{tabular}{ll}
\hline \multicolumn{1}{c}{ Immunogen } & Parity \\
\hline Control $(n=17)$ & $5.5 \pm 2.0$ \\
$60 \mathrm{kD} \mathrm{Ro}(n=12)$ & $4.8 \pm 1.9$ \\
$48 \mathrm{kD} \mathrm{La}(n=8)$ & $4.9 \pm 2.2$ \\
Calreticulin $(n=4)$ & $3.0 \pm 2.0^{*}$ \\
\hline
\end{tabular}

Values are mean $\pm \mathrm{SD}$

$* p<0.05$ compared with control, using one-way ANOVA.

children with CHB are almost always universally seen, many unaffected children are born to mothers with anti-Ro and anti-La antibodies (5-10,27-29). In addition, autopsy specimens have demonstrated the presence of antibodies, including anti-Ro and anti-La antibodies, on myocardial tissues (30-34). Taken together, these studies in humans strongly suggest a direct pathogenic effect of maternal autoantibodies on fetal and neonatal cardiac tissue. To better study the pathogenic mechanisms leading to autoantibody-mediated cardiac damage, we have adapted a previously described murine model of CHB (15) and have demonstrated echocardiographic evidence of intrauterine conduction defects.

Calreticulin is a $\mathrm{Ca}^{2+}$ binding protein. A transgenic mouse model has shown that calreticulin protein is highly expressed in the developing heart, but it is only a minor component in mature heart (35). Another mouse model has demonstrated that inadequate developmental change in expression of calreticulin caused complete heart block and sudden death (36). These 
studies in mouse suggested calreticulin might play an important role in a developing heart. Orth and colleagues (11) have reported 9 of 18 sera from mothers who had CHB children contained IgG anti-calreticulin antibodies. They suggested anti-calreticulin antibodies might influence the development of CHB. Hence, we also evaluated the effect of anti-calreticulin antibodies in this study.

Three different approaches have been used to produce a murine model of CHB. The initial study used immunization with a monoclonal anti-DNA antibody, which resulted in multiple autoantibodies including anti-Ro and anti-La antibodies (37). Offspring born to these monoclonal anti-DNA antibody-immunized female mice were noted to have varying degrees of heart block. However, as the mothers had a variety of autoantibodies, this model was not useful to determine the antibodies responsible for CHB. Similarly, the injection of pregnant mice with human IgG (containing anti-Ro and anti-La antibodies) or purified anti-Ro and anti-La antibodies may cause conduction defects in the offspring $(16,17)$. Although these experiments verified that human maternal sera can cause conduction defects in a murine system, it is a technically difficult system requiring large amounts of human sera. Other investigators have shown that a small percentage of mice born to mothers who were immunized with Ro or La proteins developed conduction defects that were detected in the neonatal period (15). In our study, we have for the first time demonstrated intrauterine bradycardia and second-degree AVB as the result of the transplacental passage of maternal autoantibodies.

Due to the difficulty in detecting "inflow-outflow" view, we could not distinguish advanced second-degree AVB and complete AVB from sinus bradycardia in fetus. A higher-resolution echocardiographic system might be able to achieve these views. A recent study has shown that tissue velocity imaging is a tool for diagnosis of human fetal arrhythmia (19). However, because a mouse fetal heart is so small, tissue velocity imaging cannot be adapted at present.

Our work supports a role for immunity directed against the Ro particle and calreticulin in the development of conduction defects. The highest percentage of first-degree AVB in neonates was detected after immunization with calreticulin followed by Ro and then La. The lowest parity, presumed to be secondary to fetal death, was seen after immunization with calreticulin. Therefore, although intermolecular spreading was seen, it appeared that antibodies directed against affinitypurified $48 \mathrm{kD}$ La were least commonly associated with conduction defects in neonates. In a previous murine model (15), neonatal ECG have shown that maternal immunity directed against $52 \mathrm{kD}$ Ro was most affected the neonatal heart conduction system, followed by $60 \mathrm{kD}$ Ro and then $48 \mathrm{kD} \mathrm{La}$, in keeping with our result. Additionally, fetal heart conduction defects were detected in all immunized groups but not in controls. Previous studies have suggested that anti-52 kD antibody was involved strongly in developing CHB $(15,17)$. However, we could not assess the effect of anti-52 kD antibody because an appropriate antigen was not available. Further work will be required to delineate the exact specificity of the pathologic antibodies that lead to CHB.
Sinus node diseases occur in a proportion of patients with neonatal lupus erythematosus and CHB. Both transient (10) and persistent (38) sinus bradycardia were reported in cases from anti-Ro/SSA-positive mothers. Exercise testing identified that $\sim 10 \%$ of patients with complete CHB also have chronotropic incompetence of the sinus node (38). Ho and colleagues $(39,40)$ have identified sinus node hypoplasia in autopsy specimens from patients dying with complete CHB. Inhibition of L-type calcium channel currents has been demonstrated in animal models of CHB (41). L-type Ca channels are important to sinus node function and are also considered to be partially responsible for the phase-4 depolarization underlying sinus node automaticity. Our model demonstrated the occurrence of significant sinus bradycardia in the presence of autoantibodies, in keeping with this broader pathophysiology.

Fetal mouse HR is higher in our study compared with that in a previous study (21). One of the causes might be differences in the sedating drug. However, our neonatal mouse HR recorded at room temperature is slower than that in other studies. We cannot exclude that the lower body temperature induced the lower HR. However, the small difference in our neonatal HR is unlikely to be critical. There is a wide variation among neonatal mouse HR, even in different studies by the same group $(15,16)$.

Neonatal ECG has been primarily used to assess for the presence of AVB in murine models of neonatal lupus erythematosus by Mazel et al. (16) and Miranda-Carus et al. (15). In the model of Mazel and colleagues (16), sinus bradycardia was seen predominately, with associated first-degree AVB. In vivo, PR interval prolongation frequently occurs in association with bradycardia, as both are influenced by cholinergic stimulation and adrenergic blockade. In the model of Miranda-Carus and colleagues (15), first-degree AVB was the predominant arrhythmia, occurring in 22 pups, and only 6 pups had more advanced degrees of heart block. Consistent with these observations, the predominant finding in our neonatal pups was also first-degree AVB. We were able to demonstrate the presence of nonadvanced second-degree AVB in up to $18 \%$ and bradycardia in up to $39 \%$ of fetuses in immunized groups. However, at birth we were only able to detect first-degree AVB. These findings could be explained either by significant reversal of conduction abnormalities by the end of birth, or by the loss of the fetuses that were affected by heart block and bradycardia. We demonstrated reduced parity in our autoantigen-immunized mice, which was most evident in the calreticulin-immunized group. Recent studies have demonstrated spontaneous intrauterine fetal death associated with CHB $(42,43)$. We suggest that the reduction in parity seen in our study in the pregnancies of autoantigen-immunized mothers can be accounted for by the death of those fetuses that were affected by bradycardia and AVB. However, we cannot exclude the possibility that some fetuses with bradycardia and AVB might recover, especially in the La group. The accurate evaluation of fetal wastage was confounded by technical problems. Firstly, fetal echocardiography could not reliably detect dead fetuses in the uterus. Secondly, we could not count stillborn pups accurately because the maternal mouse frequently consumes the stillborn pups immediately after birth. 


\section{CONCLUSION}

Using fetal echocardiography, we have demonstrated that maternal immunization with $\mathrm{Ro}$, $\mathrm{La}$, or calreticulin proteins is associated with conduction defects, which were demonstrable during gestation but not seen on ECG of surviving neonates. We suggest that the discrepancy in the incidence of fetal and neonatal conduction defects was likely secondary to fetal loss as result of cardiac damage, including damage to the conducting system. Significant fetal bradycardia and AVB may not be identified by assessment only at birth in murine models of CHB. We believe that embryonic cardiac Doppler should be regarded as a tool for this in vivo CHB model.

Acknowledgments. The authors thank Marlene Rabinovitch, Gil Gross, and Lisa Hornberger for critical guidance, appraisal, and support.

\section{REFERENCES}

1. Morquio L 1901 Sur une maladie infantile et familiale caracterisee par la mort subite. Arch Med Enfants 4:467-475

2. Yater WM 1929 Congenital heart block: review of the literature: report of a case with incomplete heterotaxy: the electrocardiogram in dextrocardia. Am J Dis Child 38:112-136

3. Chameides L, Truex RC, Vetter V, Rashkind WJ, Galioto FM Jr, Noonan JA 1977 Association of maternal systemic lupus erythematosus with congenital complete heart block. N Engl J Med 297:1204-1207

4. McCue CM, Mantakas ME, Tingelstad JB, Ruddy S 1977 Congenital heart block in newborns of mothers with connective tissue disease. Circulation 56:82-90

5. Weston WL, Harmon C, Peebles C, Manchester D, Franco HL, Huff JC, Norris DA 1982 A serological marker for neonatal lupus erythematosus. Br J Dermatol 107:377382

6. Scott JS, Maddison PJ, Taylor PV, Esscher E, Scott O, Skinner RP 1983 Connectivetissue disease, antibodies to ribonucleoprotein, and congenital heart block. N Engl J Med 309:209-212

7. Waltuck J, Buyon JP 1994 Autoantibody-associated congenital heart block: outcome in mothers and children. Ann Intern Med 120:544-551

8. Buyon JP, Waltuck J, Caldwell K, Crawford B, Slade SG, Copel J, Chan EK 1994 Relationship between maternal and neonatal levels of antibodies to $48 \mathrm{kDa}$ SSB(La), $52 \mathrm{kDa} \mathrm{SSA}(\mathrm{Ro})$, and $60 \mathrm{kDa} \mathrm{SSA}(\mathrm{Ro})$ in pregnancies complicated by congenital heart block. J Rheumatol 21:1943-1950

9. Buyon JP, Waltuck J, Kleinman C, Copel J 1995 In utero identification and therapy of congenital heart block. Lupus 4:116-121

10. Brucato A, Frassi M, Franceschini F, Cimaz R, Faden D, Pisoni MP, Muscara M, Vignati G, Stramba_Badiale M, Catelli L, Lojacono A, Cavazzana I, Ghirardello A, Vescovi F, Gambari PF, Doria A, Meroni PL, Tincani A 2001 Risk of congenital complete heart block in newborns of mothers with anti-Ro/SSA antibodies detected by counterimmunoelectrophoresis: a prospective study of 100 women. Arthritis Rheum 44:1832-1835

11. Orth T, Dorner T, Meyer Zum Buschenfelde KH, Mayet WJ 1996 Complete congenital heart block is associated with increased autoantibody titers against calreticulin. Eur J Clin Invest 26:205-215

12. Hamilton RM, Gow RM 1992 Disorders of heart rate and rhythm. In Freedom RM, Benson LN, Smallhorn JF (eds) Neonatal Heart Disease. Springer-Verlag Ltd., London, pp 777-805

13. Alexander E, Buyon JP, Provost TT, Guarnieri T 1992 Anti-Ro/SS-A antibodies in the pathophysiology of congenital heart block in neonatal lupus syndrome, an experimental model. In vitro electrophysiologic and immunocytochemical studies. Arthritis Rheum 35:176-189

14. Garcia S, Nascimento JH, Bonfa E, Levy R, Oliveira SF, Tavares AV, de Carvalho AC 1994 Cellular mechanism of the conduction abnormalities induced by serum from anti-Ro/SSA-positive patients in rabbit hearts. J Clin Invest 93:718-724

15. Miranda-Carus ME, Boutjdir M, Tseng CE, DiDonato F, Chan EK, Buyon JP 1998 Induction of antibodies reactive with SSA/Ro-SSB/La and development of congenital heart block in a murine model. J Immunol 161:5886-5892

16. Mazel JA, El Sherif N, Buyon J, Boutjdir M 1999 Electrocardiographic abnormalities in a murine model injected with IgG from mothers of children with congenital heart block. Circulation 99:1914-1918

17. Boutjdir M, Chen L, Zhang ZH, Tseng CE, DiDonato F, Rashbaum W, Morris A, el-Sherif N, Buyon JP 1997 Arrhythmogenicity of IgG and anti-52-kD SSA/Ro affinity-purified antibodies from mothers of children with congenital heart block. Circ Res 80:354-362
18. Kleinman CS, Donnerstein RL, Jaffe CC, DeVore GR, Weinstein EM, Lynch DC, Talner NS, Berkowitz RL, Hobbins JC 1983 Fetal echocardiography. A tool for evaluation of in utero cardiac arrhythmias and monitoring of in utero therapy: analysis of 71 patients. Am J Cardiol 51:237-243

19. Rein AJ, O’Donnell C, Geva T, Nir A, Perles Z, Hashimoto I, Li XK, Sahn DJ 2002 Use of tissue velocity imaging in the diagnosis of fetal cardiac arrhythmias. Circulation 106:1827-1833

20. Strasburger JF, Huhta JC, Carpenter RJ Jr, Garson A Jr, McNamara DG 1986 Doppler echocardiography in the diagnosis and management of persistent fetal arrhythmias. J Am Coll Cardiol 7:1386-1391

21. Gui YH, Linask KK, Khowsathit P, Huhta JC 1996 Doppler echocardiography of normal and abnormal embryonic mouse heart. Pediatr Res 40:633-642

22. Linask KK, Huhta JC 2000 Use of Doppler echocardiography to monitor embryonic mouse heart function. Methods Mol Biol 135:245-252

23. Scofield RH, Henry WE, Kurien BT, James JA, Harley JB 1996 Immunization with short peptides from the sequence of the systemic lupus erythematosus-associated 60-kDa Ro autoantigen results in anti-Ro ribonucleoprotein autoimmunity. J Immunol 156:4059-4066

24. Buyon JP 1996 Neonatal lupus: bedside to bench and back. Scand J Rheumatol 25:271-276

25. Buyon JP, Hiebert R, Copel J, Craft J, Friedman D, Katholi M, Lee LA, Provost TT, Reichlin M, Rider L, Rupel A, Saleeb S, Weston WL, Skovron ML 1998 Autoimmune-associated congenital heart block: demographics, mortality, morbidity and recurrence rates obtained from a national neonatal lupus registry. J Am Coll Cardiol $31: 1658-1666$

26. Isacovics B, Silverman ED 1993 Limiting dilution analysis of Epstein-Barr virus infectable B cells secreting anti-Ro/SSA and anti-La/SSB antibodies in neonatal lupus erythematosus and systemic lupus erythematosus. J Autoimmun 6:481-494

27. Julkunen H, Kurki P, Kaaja R, Heikkila R, Immonen I, Chan EK, Wallgren E, Friman C 1993 Isolated congenital heart block. Long-term outcome of mothers and characterization of the immune response to SS-A/Ro and to SS-B/La. Arthritis Rheum 36:1588-1598

28. Buyon JP, Winchester RJ, Slade SG, Arnett F, Copel J, Friedman D, Lockshin MD 1993 Identification of mothers at risk for congenital heart block and other neonatal lupus syndromes in their children. Comparison of enzyme-linked immunosorbent assay and immunoblot for measurement of anti-SS-A/Ro and anti-SS-B/La antibodies. Arthritis Rheum 36:1263-1273

29. Eberhard BA, Laxer RM, Eddy AA, Silverman ED 1991 Presence of thyroid abnormalities in children with systemic lupus erythematosus. J Pediatr 119:277-279

30. Litsey SE, Noonan JA, O'Connor WN, Cottrill CM, Mitchell B 1985 Maternal connective tissue disease and congenital heart block. Demonstration of immunoglobulin in cardiac tissue. N Engl J Med 312:98-100

31. Taylor PV, Scott JS, Gerlis LM, Esscher E, Scott O 1986 Maternal antibodies against fetal cardiac antigens in congenital complete heart block. N Engl J Med 315:667-672

32. Ishibashi-Ueda H, Yutani C, Imakita M, Kanzaki T, Utsu M, Chiba Y 1988 An autopsy case of congenital complete heart block in a newly born of a mother with systemic lupus erythematosus. Pediatr Cardiol 9:157-161

33. Reichlin M, Brucato A, Frank MB, Maddison PJ, McCubbin VR, Wolfson-Reichlin M, Lee LA 1994 Concentration of autoantibodies to native 60-kd Ro/SS-A and denatured 52-kd Ro/SS-A in eluates from the heart of a child who died with congenital complete heart block. Arthritis Rheum 37:1698-1703

34. Horsfall AC, Rose LM 1992 Cross-reactive maternal autoantibodies and congenital heart block. J Autoimmun 5:479-493

35. Mesaeli N, Nakamura K, Zvaritch E, Dickie P, Dziak E, Krause KH, Opas M, MacLennan DH, Michalak M 1999 Calreticulin is essential for cardiac development. J Cell Biol 144:857-868

36. Nakamura K, Robertson M, Liu G, Dickie P, Nakamura K, Guo JQ, Duff HJ, Opas M, Kavanagh K, Michalak M2001 Complete heart block and sudden death in mice overexpressing calreticulin. J Clin Invest 107:1245-1253

37. Kalush F, Rimon E, Mozes E 1992 Neonatal lupus erythematosus in offspring of mothers with experimental systemic lupus erythematosus. Am J Reprod Immunol 28:264-268

38. Menon A, Silverman ED, Gow RM, Hamilton RM 1998 Chronotropic competence of the sinus node in congenital complete heart block. Am J Cardiol 82:11191121, A9

39. Ho SY, Fagg N, Anderson RH, Cook A, Allan L 1992 Disposition of the atrioventricular conduction tissues in the heart with isomerism of the atrial appendages: its relation to congenital complete heart block. J Am Coll Cardiol 20:904-910

40. Ho SY, Esscher E, Anderson RH, Michaelsson M 1986 Anatomy of congenital complete heart block and relation to maternal anti-Ro antibodies. Am J Cardiol 58:291-294

41. Boutjdir M, Chen L, Zhang ZH, Tseng CE, El-Sherif N, Buyon JP 1998 Serum and immunoglobulin $\mathrm{G}$ from the mother of a child with congenital heart block induce conduction abnormalities and inhibit L-type calcium channels in a rat heart model. Pediatr Res 44:11-19

42. Jaeggi ET, Hamilton RM, Silverman ED, Zamora SA, Hornberger LK 2002 Outcome of children with fetal, neonatal or childhood diagnosis of isolated congenital atrioventricular block. A single institution's experience of 30 years. J Am Coll Cardiol 39:130-137

43. Pedra SR, Smallhorn JF, Ryan G, Chitayat D, Taylor GP, Khan R, Abdolell M, Hornberger LK 2002 Fetal cardiomyopathies: pathogenic mechanisms, hemodynamic findings, and clinical outcome. Circulation 106:585-591 